(C) 2014

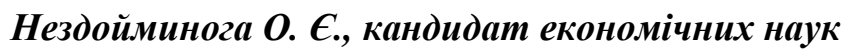

Полтавська державна аграрна академія

\title{
ПОРЯДОК ФОРМУВАННЯ ТА ВИКОРИСТАННЯ РЕЗЕРВІВ ПІД КРЕДИТНІ РИЗИКИ В БАНКАХ УКРАЇНИ
}

\section{Рецензент - доктор економічних наук, професор В. Я. Плаксієнко}

Досліджено основні тендениії у здійсненні банківськими установами активних операцій. Визначено сутність кредитного ризику, зовнішніх та внутрішніх факторів впливу на нього. Розглянуто класифікаиію кредитного портфеля банку та охарактеризовано категорії кредитних операцій за рівнем кредитного ризику й відповідні норми відрахувань до резерву під кредитні ризики банків України. Висвітлено порядок формування й використання резервів під кредитні ризики банків України. Узагальнено основні методи регулювання кредитних ризиків.

Ключові слова: кредитні операчиї, кредитний портфель банку, кредитний ризик, резерв під кредитні ризики, метод регулювання кредитними ризиками.

Постановка проблеми. Банківська діяльність нерозривно пов'язана з ризиком. Кожен комерційний банк вирішує проблему максимального прибутку за оптимального рівня ризику.

На сьогодні домінуюче положення серед усіх можливих ризиків для вітчизняних банків посідає кредитний ризик. Погіршення фінансового стану позичальників, що створює перешкоди та унеможливлює розрахунки за власними зобов'язаннями перед комерційними банками, змушує останні вживати відповідних заходів щодо мінімізації кредитних ризиків для забезпечення стабільності діяльності. Одним із найважливіших інструментів в управлінні кредитними ризиками $\epsilon$ створення резервів під кредитні операції комерційних банків.

Створення банком внутрішніх резервів кредитних ризиків за рахунок його доходів та забезпечення прибутковості діяльності $\epsilon$ взаємозалежними і водночас протинаправленими процесами, що потребують наразі дослідження.

Аналіз останніх досліджень та публікацій, у яких започатковано розв'язання проблеми. Становлення конкурентоздатної економіки України потребує забезпечення високого рівня стійкості банківської системи, що сприяє прискоренню руху банківських ресурсів, стимулюванню інноваційно-інвестиційної діяльності банківської установи та задоволенню фінансових потреб населення. В умовах негативного впливу фінансово-економічної кризи на діяльність вітчизняних банків існує тенденція погіршення якості кредитного портфеля, що призводить до збитковості банківських установ.

Дослідженню теоретико-методологічних основ банківського кредитування, якості кредитного портфеля, проблемам захисту банків від кредитних ризиків та сучасного механізму формування резервів по кредитним операціям присвячені наукові праці вітчизняних дослідників М. Білика, В. Вітлінського, О. Корєнєвої, Л. Симановського та зарубіжних - П. Роуз, Дж. Сінкі, Дж. Стігліца [7, 9].

Мета і завдання дослідження. Метою даної статті $€$ визначення порядку формування та використання резервів під кредитні ризики.

Завданням є висвітлення основних чинників, що впливають на обсяг резервів під кредитні ризики банківських установ, порядок їх формування, використання та управління.

Матеріали і методи досліджень. Матеріалами досліджень $€$ наукові праці вітчизняних і зарубіжних дослідників, а також нормативно-правові документи, що пов'язані з темою дослідження.

Методами досліджень $є$ узагальнення та систематизація, а також аналіз і синтез.

Результати дослідження. Кредитні операції це вид активних операцій банків, пов'язаних із наданням клієнтам коштів у тимчасове користування або прийняття зобов'язань про надання коштів у тимчасове користування за певних умов, а також надання гарантій, поручительств, авалів, розміщення депозитів, проведення факторингових операцій, фінансового лізингу, видача кредитів у формі врахування векселів, у формі операцій репо, будь-яке продовження строку погашення боргу, надане в обмін на зобов' язання боржника щодо повернення заборгованої суми, а також на зобов'язання на сплату процентів та інших зборів з такої суми (відстрочення платежу) [3].

Банки в процесі здійснення своєї діяльності несуть різноманітні ризики. Одним з економічних ризиків комерційних банків $\epsilon$ кредитний, що являє собою ймовірність невиконання контраге- 


\section{EKOHOMIKA}

нтом власних зобов'язань перед банком по поверненню основної суми боргу та/або суми винагороди банку (процентів).

На кредитний ризик впливають певні зовнішні та внутрішні фактори, що носять, відповідно, неконтрольований i контрольований характер. Зовнішні фактори відбуваються 3 причин, незалежних від діяльності персоналу кредитного підрозділу банку. Внутрішні фактори, навпаки, відбуваються з причин, зумовлених прорахунками персоналу, допущеними в процесі оформлення кредитного договору, помилками в оцінці надійності клієнта, порушеннями посадових інструкцій і помилками, що можуть зустрічатися в самих правилах кредитування.

Згідно з даними НБУ (табл. 1), частка простроченої заборгованості у загальній сумі кредитів, наданих банками України, досягла найвищого рівня у 2010 році (11,2 \%). За 2011-2013 рр. спостерігається помітне зменшення даного показника, що є позитивним зрушенням і свідчить про здійснення правильної політики кредитування банківськими установами. Показник частки простроченої заборгованості за наданими кредитами за I півріччя 2014 р. становить 10,1 \%, що обумовлено, передусім, кризовою ситуацією у державі [5]. Для підвищення надійності та стабільності банківської системи, захисту кредиторів і вкладників банки формують резерви для покриття можливих втрат від проведення актив- них операцій [2].

Законодавчо визначено конкретний перелік заборгованостей за кредитними операціями, що становлять кредитний портфель банку [6]. Положення «Про порядок формування та використання резерву для відшкодування можливих втрат за кредитними операціями банків» № 23 від 25 січня 2012 року визначає також операції, за якими банк не здійснює формування резервів, а саме:

- кредитними операціями між установами в системі одного банку (для банків із $100 \%$ іноземним капіталом - за розрахунками з материнською компанією, якщо ця компанія має кредитний рейтинг не нижчий, аніж «інвестиційний клас»);

- коштами в іноземній валюті, що перераховані НБУ.

Із метою розрахунку резерву під кредитні ризики банки мають здійснювати класифікацію кредитного портфеля за кожною кредитною операцією залежно від фінансового стану позичальника, стану обслуговування позичальником кредитної заборгованості та 3 урахуванням рівня забезпечення кредитної операції.

За результатами класифікації кредитного портфеля визначається категорія кожної кредитної операції: «стандартна», «під контролем», «субстандартна», «сумнівна» чи «безнадійна» (табл. 2).

\section{1. Динаміка та структура показників обсягу наданих кредитів і резервів за активними операціями банків Украӥни}

\begin{tabular}{|c|c|c|c|c|c|c|c|c|}
\hline \multirow{2}{*}{ Назва показника } & \multicolumn{7}{|c|}{ Роки } \\
\cline { 2 - 9 } & 2007 & 2008 & 2009 & 2010 & 2011 & 2012 & 2013 & $\begin{array}{c}\text { I півріччя } \\
2014 \text { р. }\end{array}$ \\
\hline $\begin{array}{c}\text { Кредити надані, } \\
\text { млн грн }\end{array}$ & 485368 & 792244 & 747348 & 755030 & 825320 & 815327 & 911402 & 1017798 \\
\hline $\begin{array}{c}\text { Частка простро- } \\
\text { ченої заборгова- } \\
\begin{array}{c}\text { ності у загальній } \\
\text { сумі кредитів, \% }\end{array}\end{array}$ & 1,3 & 2,3 & 9,4 & 11,2 & 9,6 & 8,9 & 7,7 & 10,1 \\
\hline $\begin{array}{c}\text { Резерви за актив- } \\
\text { ними операціями } \\
\text { банків, млн грн }\end{array}$ & 20188 & 48409 & 122433 & 148839 & 157907 & 141319 & 131252 & 160640 \\
\hline $\begin{array}{c}\text { Частка резервів } \\
\text { за активними } \\
\text { операціями у } \\
\text { загальній сумі } \\
\text { кредитів, \% }\end{array}$ & 4,2 & 6,1 & 16,4 & 19,7 & 19,1 & 17,3 & 14,4 & 15,8 \\
\hline
\end{tabular}




\section{ЕКОНОМІКА}

\section{2. Характеристика категорій кредитних операцій за рівнем кредитного ризику}

\begin{tabular}{|c|c|}
\hline $\begin{array}{c}\text { Категорія } \\
\text { кредитної операції }\end{array}$ & Характеристика кредитного ризику \\
\hline Стандартні & кредитний ризик $є$ незначним і становить два відсотки чистого кредитного \\
ризику
\end{tabular}

Джерело: сформовано автором за даними [6]

Резерв під кредитні ризики використовується лише для покриття збитків від непогашеної позичальниками заборгованості за кредитними операціями за основним боргом, стягнення якої $\epsilon$ неможливим і формується в тій валюті, в якій враховується заборгованість [4].

Визначаючи розмір резерву, комерційні банки здійснюють класифікацію виданих кредитів i депозитів та оцінюють кредитні ризики з урахуванням таких чинників: фінансового стану позичальника; стану обслуговування позичальником кредитної заборгованості; рівня забезпечення кредитної операції.

У бухгалтерському обліку банки зобов'язані здійснювати формування резервів щомісяця в повному обсязі незалежно від обсягів їх доходів за групами ризику відповідно до сум заборгованості за кредитними операціями станом на перше число місяця, наступного за звітним, до встановленого строку для подання оборотносальдового балансу (щомісяця).
Для цілей розрахунку резервів на покриття можливих втрат за кредитними операціями банк визначає чистий кредитний ризик (в абсолютних показниках) за кожною окремою кредитною операцією зважується на встановлений коефіцієнт резервування (табл. 3).

Із метою розрахунку обсягу резерву під кредитні ризики та визначення чистого кредитного ризику банк повинен проаналізувати кредитний портфель. Аналіз кредитного портфеля та класифікація кредитних операцій (валового кредитного ризику) здійснюється за такими критеріями: оцінка фінансового стану позичальника (контрагента банку); стан обслуговування позичальником (контрагентом банку) кредитної заборгованості за основним боргом і відсотків (комісій та інших платежів 3 обслуговування боргу) за ним у розрізі кожної окремої заборгованості та спроможність позичальника надалі обслуговувати цей борг; рівень забезпечення кредитної операції [4].

\section{3. Норми відрахувань до резерву під кредитні ризики банків Украӥни}

\begin{tabular}{|c|c|}
\hline Категорія кредитної операції & Коефіцієнт резервування (за ступенем ризику) \\
\hline Стандартна & $2 \%$ \\
\hline Під контролем & $5 \%$ \\
\hline Субстандартна & $20 \%$ \\
\hline Сумнівна & $50 \%$ \\
\hline Безнадійна & $100 \%$ \\
\hline
\end{tabular}




\section{ЕКОНОМІКА}

Дестабілізаційні процеси в економіці України в останні роки, що характеризуються девальвацією національної валюти, падінням обсягів ВВП та промислового виробництва, зумовлюють негативні тенденції в діяльності банківських установ [1].

Збільшення частки простроченої заборгованості у кредитному портфелі банку змушує їх керівництво застосовувати всі можливі методи регулювання кредитними ризиками.

Діяльність ризик-менеджменту направлена на розробку дієвого механізму управління кредитним ризиком, адже саме від цього залежить якість кредитного портфеля банку.

Суттєвим $є$ визначення основних методів управління кредитними ризиками та використання їх у практичній діяльності. До них належать:

- організаційно-управлінські: створення у банку структурного підрозділу з регулювання кредитними ризиками; формування чіткої системи делегування повноважень; поетапна організація кредитного процесу, у тому числі документообороту; підвищення кваліфікації персоналу;

- методологічні: встановлення кредитних рейтингів контрагентів банку 3 подальшою системою преміювання у сфері кредитних відносин; розробка та застосування методів оцінки кредитоспроможності контрагентів банку;

- законодавчі: створення та використання резервів на відшкодування можливих втрат за кредитними операціями банку з урахуванням загальноприйнятої методики; суворе дотримання законодавчих процедур кредитування;

- інформаційні: формування внутрішньої інформаційної бази даних, що забезпечить отримання повної та достовірної інформації про кредитну історію клієнтів; формування взаємовідносин між банківськими установами; зовнішне інформування банківських установ із метою встановлення довгострокових прогнозів;

- контрольні: моніторинг і контролінг ризиків (внутрішній та зовнішній); юридичний контроль; документальний контроль.

У загальному методи управління кредитними ризиками поділяються на дві групи:

- методи управління кредитним ризиком на рівні окремого кредиту;

\section{БІБЛІОГРАФІЯ}

1. Дробніцька О. Р. Проблемні кредити банків: сучасний стан та можливості управління ними через процес сек' юритизації активів / О. Р. Дробніцька // Інноваційна економіка. - 2013. - № 6(44). C. 267-272.

2. Журавка Ф. О. Методичні аспекти обліку
- методи управління кредитним ризиком на рівні кредитного портфеля банку.

До методів управління ризиком окремого кредиту належать:

- аналіз кредитоспроможності позичальника;

- аналіз та оцінка кредиту;

- контроль за наданим кредитом і станом застави.

Особливість перелічених методів полягає у необхідності їх послідовного застосування, поскільки одночасно вони є етапами процесу кредитування. Якщо на кожному етапі перед кредитним працівником поставлено завдання мінімізації кредитного ризику, то правомірно розглядати етапи процесу кредитування як методи управління ризиком окремої позички.

Методи управління ризиком кредитного портфеля банку:

- диверсифікація;

- лімітування;

- створення резервів для відшкодування втрат за кредитними операціями комерційних банків;

- сек'юритизація.

Проведені дослідження доводять, що повне уникнення кредитних ризиків, навіть у разі застосування максимально можливої кількості методів їх регулювання, неможливе. У цьому питанні, на нашу думку, вирішальну роль відіграє так званий «людський» чинник, тобто кваліфікованість персоналу кредитного відділу банку (освіта, досвід, професійні та індивідуальні якості в роботі).

Виснвок. Дане дослідження доводить, що процес формування резервів під кредитні ризики $\epsilon$ досить важливою частиною формування кредитної політики банків у цілому й потребує врахування багатьох зовнішніх та внутрішніх факторів і відповідального підходу з боку фахівців та керівництва. Суттєвим механізмом забезпечення прибутковості діяльності комерційного банку є розробка дієвого механізму управління кредитними ризиками, що полягає в застосуванні відповідних організаційно-економічних, методологічних, інформаційних, законодавчих і контрольних методів регулювання, i, безумовно, кваліфікованого персоналу.

формування та використання резервів за міжбанківськими кредитами [Електронний ресурс] / Ф. О. Журавка. - Режим доступу : http://www. economy.nayka.com.ua/?op $=1 \& z=1776$

3. Закон України «Про банки і банківську діяльність» № 2121-III від 7 грудня 2000 р. України 


\section{EKOHOMIKA}

[Електронний ресурс]. - Режим доступу : http://www.bank.gov.ua.

4. Мисак Г. Методологічні особливості обліку резервів під кредитні ризики банків / Г. Мисак // Вісник Київського Національного університету ім. Т. Г. Шевченка. - 2007. - № 92. - С. 15-17.

5. Офіційний сайт Національного банку України [Електронний ресурс]. - Режим доступу : http://www.bank.gov.ua.

6. Постанова Правління НБУ «Про затвердження «Положення про порядок формування та використання резерву для відшкодування можливих втрат за активними банківськими операціями» № 23 від 25 січня 2012 р. [Електронний peсурс]. - Режим доступу : http://zakon3.rada. gov.ua/laws/show/z0231-12.

7. Синки Дж. Мл. Управление финансами в комерческом банке : пер. с англ. / Синки Дж. Мл. - M. : Catallaxy, 1994. - 820 c.

8. Формування резервів під кредитні операції банку в умовах фінансової кризи [Електронний pecypc]. - Режим доступу : http://www.rusnauka. com/6_PNI_2013/Economics/1_130261.doc.htm

9. Хімчук Г. О. Резерви на можливі витрати по позичках у банківській діяльності [Текст] / Г. О. Хімчук // Економіка : Наукові праці. Том 99. - Вип. 86. - К., 2007. - С. 57-60. 